\author{
Tomasz TRZEPIECIŃSKI ${ }^{1}$ \\ Romuald FEJKIEL ${ }^{2}$ \\ Andrzej KUBIT ${ }^{3}$
}

\title{
EXPERIMENTAL EVALUATION OF VALUE OF FRICTION COEFFICIENT IN THE DRAWBEAD REGION
}

\begin{abstract}
Drawbeads are supposed to change the stress state of sheets in specific areas of the sheet material, or compensate for material flow at the periphery of the drawpiece, especially when forming complex shaped thin-walled products. The article presents the results of frictional resistance testing of a DC04 steel sheet using a drawbead simulator test. Experimental investigations were carried out using a special device that allows a change in the degree of deformation of the sheet metal on the drawbead. Specimens were tested for: (i) three degrees of sheet deformation; (ii) three countersamples' surface roughness; and (iii) three lubrication conditions: dry friction, machine oil lubrication and paint lubrication. The test specimens were cut out along, and transversely to, the direction of rolling of the sheet metal. The basic relations between technological parameters of friction test and coefficient of friction were determined.
\end{abstract}

Keywords: coefficient of friction, drawbead, drawbead simulator, friction

\section{Introduction}

The value of the frictional resistance occurring in the sheet metal forming processes depends on several parameters; i.e. the mechanical properties of the material, the lubrication conditions, the topography both of sheet and the tools and the forming process parameters (temperature, load dynamics, etc.) [1, 2]. The friction tests simulating friction and lubrication conditions in sheet metal forming can be divided into tests which simulate processes and tests which simulate tribological conditions [3]. These tests simulate friction conditions in the specific contact areas between the sheet and tools. Tribology trials and tribological conditions

\footnotetext{
${ }^{1}$ Autor do korespondencji/corresponding author: Tomasz Trzepieciński, Rzeszow University of Technology, 12 Powstańców Warszawy Ave., 35-959 Rzeszow, tel.: (17) 8651714, e-mail: tomtrz@prz.edu.pl

${ }^{2}$ Romulad Fejkiel, State School of Higher Vocational Education in Krosno, e-mail: rfejkiel@wp.pl

${ }^{3}$ Andrzej Kubit, Rzeszow University of Technology, e-mail: akubit@prz.edu.pl
} 
are divided into methods with indirect or direct measurement of frictional resistance values. Both mentioned groups of tests can be divided into tests with the direct or indirect measurement of friction coefficient values. In indirect measuring tests, the coefficient of friction is determined based on the measurement of other physical quantities, such as friction and normal forces. The coefficient of friction is calculated based on the assumed friction model. Experimental tests of the friction coefficient value only allow the determination of friction resistance in selected areas of the drawpiece, which leads to the need to use multiple friction tests [4-6].

The friction test modelling the frictional phenomena on the drawbead has been developed by Nine [7]. The drawbeads are used in the sheet forming of complex-shape drawpieces to compensate for the material flow resistance around the circumference of a drawpiece, or to change the stress state at specific locations on the drawpiece. In some cases, the required blankholder force may exceed the press capacity [8]. Therefore, in the forming of asymmetric drawpieces, such as large autobody panels, where the restraining force required to slow down the metal flow is very high, the use of drawbeads is necessary $[8,9]$. The curvature of the sheet when passing through the drawbead changes several times: the sheet is, in turn, bent and unbent. When passing the sheet through the drawbead, the deformation resistance and the frictional resistances between the drawbead and the sheet must be overcome. The idea of Nine's simulator construction is to separate the deformation resistance of the sheet from the frictional resistances. The change in friction conditions in the drawbead simulator is obtained by changing the angle of the roll wrapping $[10,11]$, the lubrication conditions $[10,12]$, the shape and dimensions of the drawbead model [13] and the drawing speed [12,13].

This paper presents the results of frictional resistance investigations of a DC04 steel sheet. Experiments were carried out using a drawbead simulator. The sheets were tested for three degrees of sheet deformation, three rolls with different roughness, and three lubrication conditions.

\section{Material and method}

DC04 steel sheets with a thickness of $0.8 \mathrm{~mm}$ were used as the test materials. Tensile tests in a Zwick Roell Z030 universal testing machine were carried out to determine the mechanical properties of the sheets. The mechanical properties (Tab. 1) determined in these tests were yield stress $R_{p 0.2}$, ultimate strength $R_{m}$, elongation $\mathrm{A}$, anisotropy coefficient $\mathrm{r}$, strain-hardening coefficient $\mathrm{C}$ and strainhardening exponent $\mathrm{n}$. The measurement of surface roughness parameters was carried out using a Talysurf CCI Lite 3D instrument. The selected standard 3D parameters (Tab. 2) determined by this measurement were: roughness average Sa, root mean square roughness parameter Sq, maximum pit depth $\mathrm{Sv}$, highest peak of the surface Sp, surface skewness Ssk, maximum profile height $\mathrm{Sz}$, root mean square gradient Sdq, and the developed interfacial area ratio Sdr. 
Table 1. Selected mechanical properties of tested DC04 steel sheet

\begin{tabular}{|c|c|c|c|c|c|}
\hline $\begin{array}{c}\text { Sample } \\
\text { orientation }\end{array}$ & $\mathrm{R}_{\mathrm{p} 0,2, \mathrm{MPa}}$ & $\mathrm{R}_{\mathrm{m}}, \mathrm{MPa}$ & $\mathrm{A}, \%$ & $\mathrm{C}, \mathrm{MPa}$ & $\mathrm{n}$ \\
\hline $0^{\circ}$ & 185.4 & 303.9 & 23.0 & 490.4 & 0.205 \\
\hline $45^{\circ}$ & 193.7 & 314.9 & 22.1 & 489.9 & 0.164 \\
\hline $90^{\circ}$ & 176.1 & 296.0 & 22.8 & 465.7 & 0.169 \\
\hline
\end{tabular}

Table 2. Basic surface roughness parameters of tested DC04 steel sheet

\begin{tabular}{|c|c|c|c|c|c|c|c|}
\hline $\mathrm{Sa}, \mu \mathrm{m}$ & $\mathrm{Sq}, \mu \mathrm{m}$ & $\mathrm{Sp}, \mu \mathrm{m}$ & $\mathrm{Sv}, \mu \mathrm{m}$ & $\mathrm{Sz}, \mu \mathrm{m}$ & Ssk & Sdq & Sdr \\
\hline 1.178 & 1.467 & 8.628 & 9.273 & 17.902 & -0.128 & 2.970 & 0.265 \\
\hline
\end{tabular}

To determine frictional resistances, friction tests were carried out using the drawbead simulator (Fig. 1). The design of the simulator allows changes in the frictional resistances of the sheet by changing the angle of wrapping of the middle roll (see 2, Fig. 1). The frame (5) of the friction simulator was attached to the lower grip of the Zwick Roell Z030 tensile testing machine, and the tension member (6) was attached to the upper grip of testing machine. During the tests, using two tension gauges ( 7 and 8 ), the pulling force and the clamping force were registered by the computer program. One specimen was pulled between freely rotated cylindrical rolls, and then the measured pulling force and the clamping force gave the bending and unbending resistance of the sheet under 'frictionless' conditions, respectively [14]. The sheet was displaced between the rotating rolls so that the friction between the sheet and rolls was minimized whereas the second specimen was pulled between the fixed rolls [2]. The coefficient of friction value was calculated according to the expression:

$$
\mu=\frac{F_{C}^{Z}-F_{C}^{r}}{F_{D}^{Z}} \cdot \frac{\sin \Theta}{2 \Theta}
$$

where $\mathrm{F}_{\mathrm{C}}^{\mathrm{z}}$ is the pulling force obtained with the fixed rolls, $\mathrm{F}_{\mathrm{C}}^{\mathrm{r}}$ is the pulling force obtained with the freely rotating rolls, $\mathrm{F}_{\mathrm{D}}^{\mathrm{Z}}$ is the normal force or clamping force obtained with the fixed beads, and $\theta$ is the quarter contact angle of actual engagement of the strip over the bead (Fig. 2).

Various tribological conditions were obtained using rolls with different surface roughness values $(\mathrm{Ra}=0.32,0.64$ and $1.25 \mu \mathrm{m})$, measured along the generating line of the rolls. Prior to each friction test, the surface of the rolls was checked and the surface was cleaned with acetone to remove potential products of the abrasive wear of DC04 surface roughness. Machine oil L-AN 46 with 44 $\mathrm{mm}^{2} \mathrm{~s}^{-1}$ viscosity at $40^{\circ} \mathrm{C}$ was used for lubricated conditions. As a second lubricant, methacrylic resin was used combined with chlorinated hydrocarbons. 


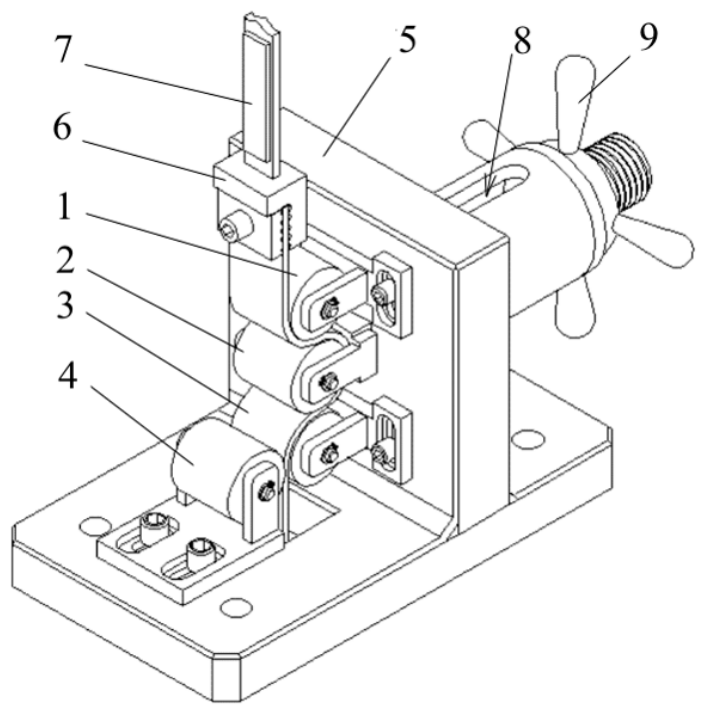

Fig. 1. Measurement system used for friction testing; 1 - front roll, 2 - middle roll, 3 - back roll, 4 - supporting roll, 5 - frame, 6 - tension member, 7 and 8 - extensometers, 9 - handwheel

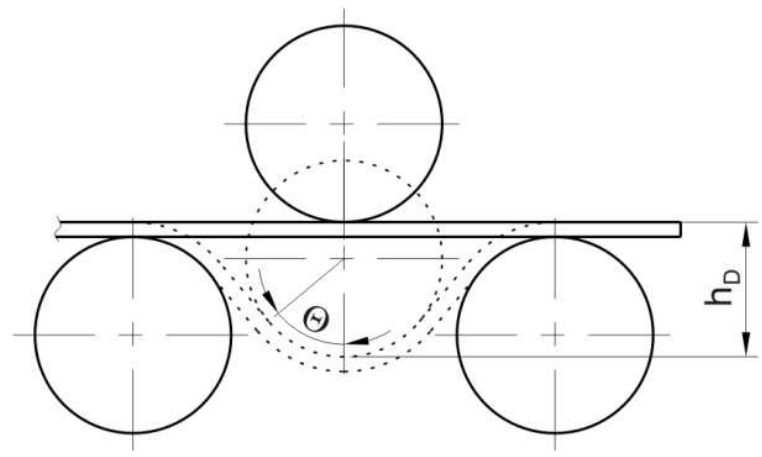

Fig. 2. Model of drawbead

\section{Results and discussion}

After starting the friction test the load forces values were characterized by high oscillations (Fig. 3a). The coefficient of friction for a given test was determined as the mean value of its course during the stabilized friction process (Fig. $3 b$ ). In the analyses, the initial transient scope of the load forces was rejected. In the case of dry friction and oil lubrication for a sample width of $7 \mathrm{~mm}$, the friction coefficient value decreased with an increase in the middle roll displacement (Fig. 4a), whereas for the threefold sample the inverse relationship was noticed (Fig. $4 \mathrm{~b})$. For a sample width of $14 \mathrm{~mm}$, the recorded friction coefficient values were the most similar across the whole range of middle roll displacement. 

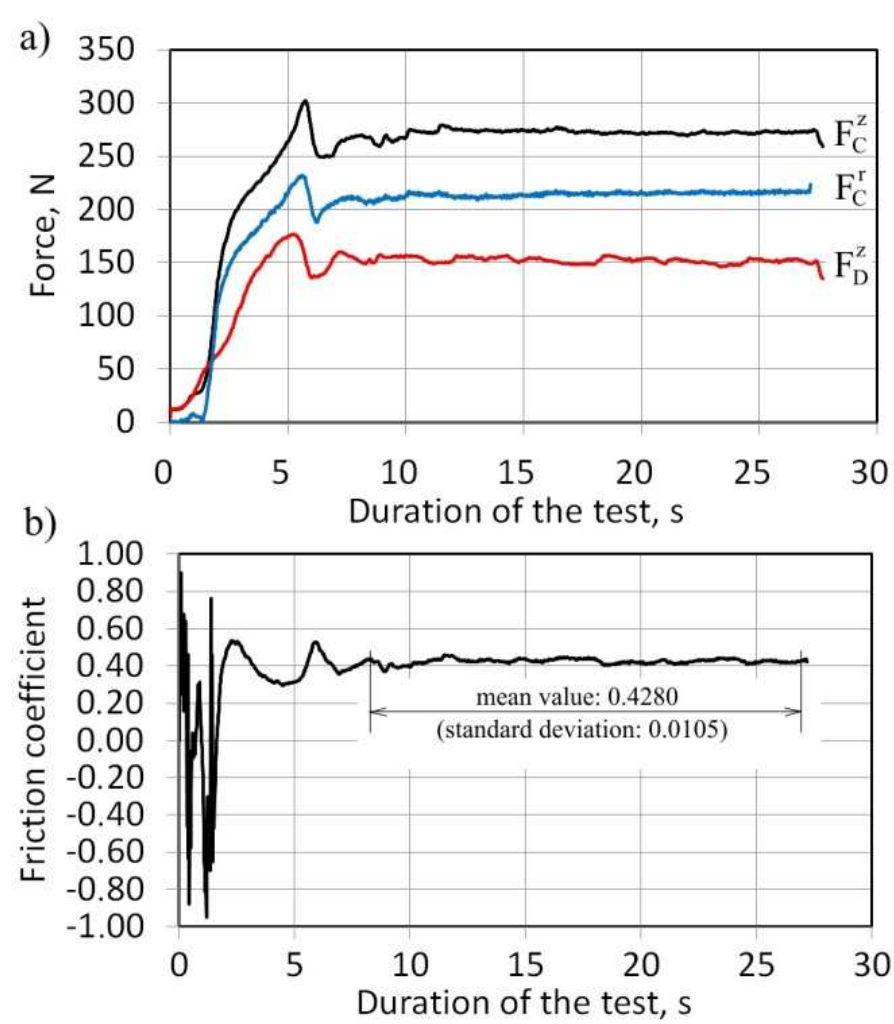

Fig. 3. Variation of load forces: (a) $F_{C}^{\mathrm{Z}}, \mathrm{F}_{\mathrm{C}}^{\mathrm{r}}, \mathrm{F}_{\mathrm{D}}^{\mathrm{Z}}$, and (b) friction coefficient values under following conditions: Ra of rolls $1.25 \mu \mathrm{m}$, dry friction, sample orientation at $0^{\circ}$

The change in the friction coefficient in a drawbead test is related to the change in the forced parameters of strip pulling in directions which do not overlap the direction of the strip pulling. Changing the strip width determined the character of strip deformation on the width and determined the change in the actual contact surface. The increase in the middle roll displacement increased the effect of the non-linear strain hardening and the yield stress of the sheet material. The resistance of sheet pulling in the drawbead increased with strain hardening. Thus, the relation between forces used to evaluate the friction coefficient (Eq. (1)) varied.

The effectiveness of reducing the friction coefficient value depends on the lubrication conditions and the displacement of the middle roll. The highest efficiency of the applied lubricant in reducing the frictional resistance was observed during the lubrication of the sheet with methacrylic resin. For the samples cut in the direction of sheet rolling, poorer efficiency in decreasing the friction coefficient value by the two analysed lubricants is achieved. 


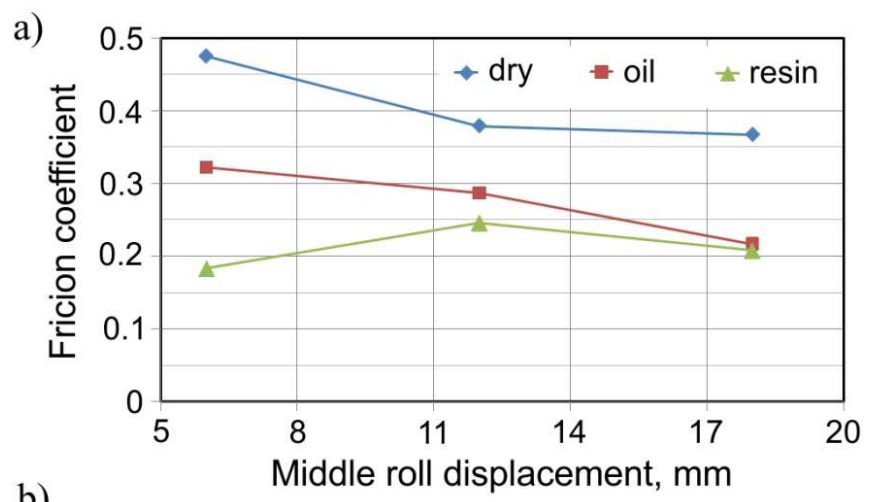

b)

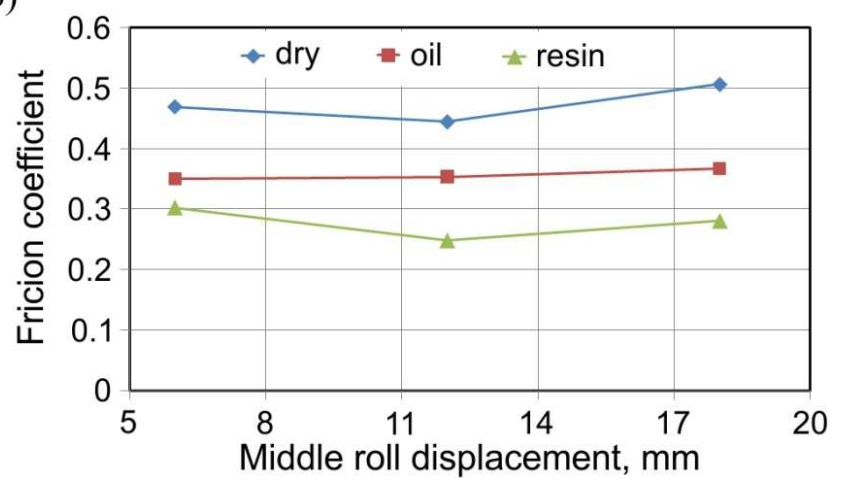

Fig. 4. Friction coefficient value vs. displacement of middle roll with roughness $\mathrm{Ra}=1.25 \mu \mathrm{m}$ for strip widths: (a) 7 and (b) $20 \mathrm{~mm}$

In the range of applied displacements of the middle roll, increasing the value of this parameter made it possible to stabilize the friction coefficient values for different sample widths (Fig. 5a, b). With the increase in the roughness of the middle roll, a tendency to increase the friction coefficient was observed in the range of middle roll displacement of 6-12 mm (Fig. 6). However, for higher values of roll roughness, the increase in middle roll displacement did not affect the coefficient of friction value significantly. Similar results were observed for the other sample widths and lubrication conditions. The friction coefficient values determined for both sample orientations were close to each other (Fig. 7). In all tested friction conditions, the friction coefficient difference between the two orientations did not exceed 0.008-0.012. 
a)

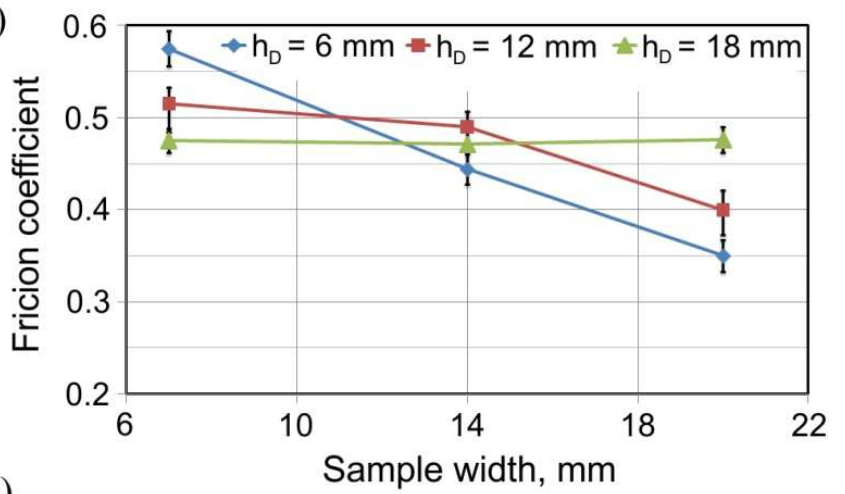

b)

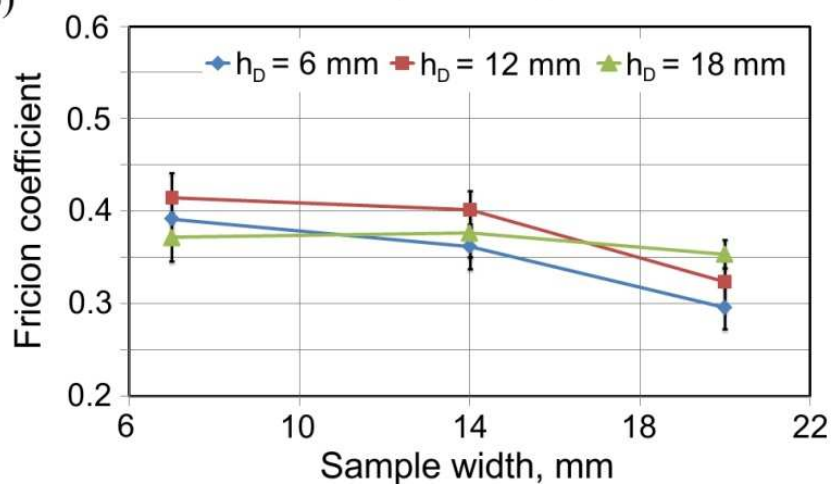

Fig. 5. Effect of strip width on value of friction coefficient under following conditions: $\mathrm{Ra}$ of rolls $0.32 \mu \mathrm{m}$, friction conditions: (a) dry friction and (b) oil lubrication

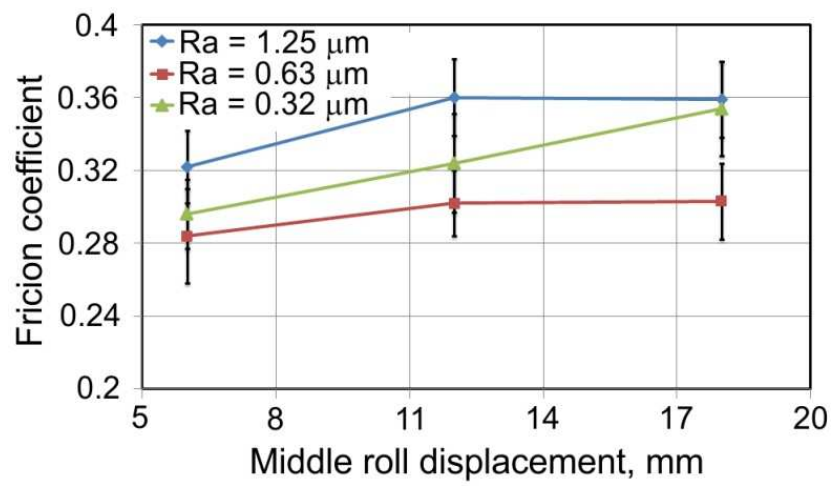

Fig. 6. Effect of roll roughness on value of friction coefficient under following conditions: oil lubrication, strip width $20 \mathrm{~mm}$, strip orientation $0^{\circ}$ 


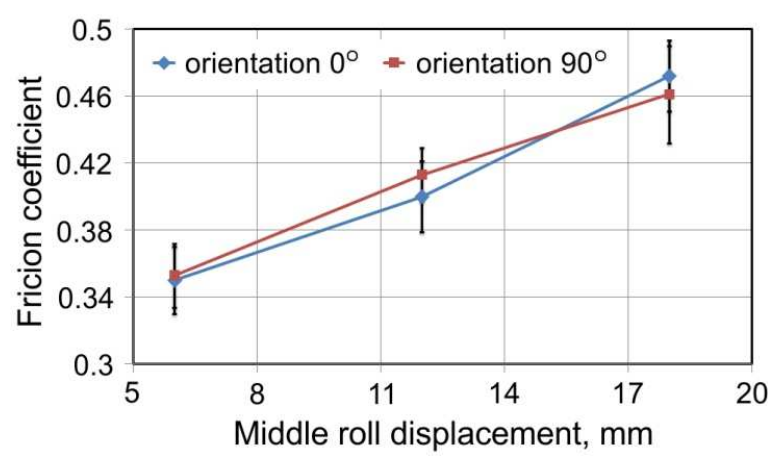

Fig. 7. Effect of strip orientation on value of friction coefficient under following conditions: Ra of rolls $0.32 \mu \mathrm{m}$, strip width $20 \mathrm{~mm}$, dry friction

\section{Summary and conclusions}

The effectiveness of reducing frictional resistance during pulling a sheet at the drawbead depends not only on the used lubricant, but also on the displacement of the middle roll. In the case of the greatest displacement of middle roll $\left(\mathrm{h}_{\mathrm{D}}=18 \mathrm{~mm}\right)$, the smallest differences were observed in the friction coefficient values determined for the different strip widths.

The coefficient of friction determined using the drawbead simulator cannot be identified as the Amontons-Coulomb coefficient, because the direction of pulling force action does not overlap the curvature of the drawbead. Furthermore, for small values of displacement $h_{D}$ of the middle roll, and for various strip widths, the shape of the friction contact surface is not a representation of the shape of the cylindrical roll. Comparing determined values of friction coefficient with the results of other friction tests, the kinematics of friction process should be taken into account.

\section{References}

[1] Trzepieciński T.: Badania oporów tarcia wywołanych działaniem progów ciągowych w procesie kształtowania blach, Hutnik, 55 (2010) 345-349.

[2] Trzepieciński T., Lemu H.G.: Study on frictional conditions of AA5251 aluminium alloy sheets using drawbead simulator test and numerical methods, J. Mech. Eng., 60 (2014) 51-60.

[3] Świątkowski K.: Sposoby oceny wielkości tarcia na powierzchniach kontaktu niemetalicznego materiału modelowego i narzędzia, Obróbka Plastyczna, 7 (2000) 21-30.

[4] Bay N., Olsson D.D., Andreasen J.L.: Lubricant test methods for sheet metal forming, Tribol. Int., 41 (2008) 844-853.

[5] Kalpakjian S.: Recent progress in metal forming tribology, J. App. Metalworking, 4 (1986) 270-280. 
[6] Schey J.A.: Tribology in metalwoking. Friction, lubrication and wear, Metals Park American Society for Metals 1983.

[7] Nine H.D.: Draw bead forces in sheet metal forming, Proceedings of a Symposium on Mechanics of Sheet Metal Forming: Behaviour and Deformation Analysis, Plenum Press, Warren 1978, pp. 179-211.

[8] Jang J.H., Kim W.T., Van Tyne C.J., Moon Y.H.: Experimental analysis on the frictional behaviour of drawbeads in sheet metal forming, Steel Res. Int., 78 (2007) 884-889.

[9] Tufekci S.S., Wang C., Kinzel G., Altan T.: Estimation and control of drawbead forces in sheet metal forming, SAE Paper No. 940941, 1994.

[10] Samuel M.: Influence of drawbead geometry on sheet metal forming, J. Mater. Process. Technol., 122 (2002) 94-103.

[11] Smith L.M., Zhou Y.J., Zhou D.J., Wanintudal C.: A new experimental test apparatus for binder draw bead simulations, J. Mater. Process. Technol., 209 (2009) 4942-4948.

[12] Figueiredo L., Ramalho A., Oliveira M.C., Menezes L.F.: Experimental study of friction in sheet metal forming, Wear, 271 (2011) 1651-1657.

[13] Lanzon J.M., Cadew-Hall M.J., Hodgson P.D.: Characterizing frictional behaviour in sheet metal forming, J. Mater. Process. Technol., 80-81 (1998) 251-256.

[14] Trzepieciński T.: Wybrane aspekty oceny tribologicznej blach odkształcanych plastycznie, OW PRz, Rzeszów 2014.

\section{EKSPERYMENTALNE WYZNACZANIE WARTOŚCI WSPÓŁCZYNNNIKA TARCIA W OBSZARZE PROGU CIĄGOWEGO}

\section{Streszczenie}

Zadaniem progów ciągowych jest zmiana stanu naprężenia materiału w określonych obszarach blachy lub wyrównanie płynięcia materiału na obwodzie wytłoczki, szczególnie podczas kształtowania wytłoczek o złożonym kształcie. W artykule przedstawiono wyniki badań oporów tarcia blachy stalowej DC04. Badania eksperymentalne zrealizowano za pomocą specjalnego przyrządu umożliwiającego zmianę stopnia odkształcenia blachy na progu ciągowym. Blachy testowano dla trzech stopni odkształcenia, trzech chropowatości rolek oraz trzech warunków smarowania: tarcie suche, smarowanie olejem maszynowym oraz smarowanie żywicą metakrylową. Próbki do badań wycięto wzdłużnie i poprzecznie względem kierunku walcowania arkusza blachy. Wyznaczono podstawowe zależności pomiędzy parametrami technologicznymi próby tarcia a wartością współczynnika tarcia.

Słowa kluczowe: współczynnik tarcia, próg ciągowy, symulator progu ciągowego, tarcie

DOI: $10.7862 / \mathrm{rm} .2018 .07$

Otrzymano/received: 19.09 .2017

Zaakceptowano/accepted: 20.12.2017 
